\title{
O DESENVOLVIMENTO DA DRENAGEM SUSTENTÁVEL DE UMA AVENIDA
}

\section{EDUARDO FREGULIA FRANÇA | UNESC FLÁVIA CAUDURO | UNESC}

\section{INTRODUÇÃO}

Os problemas do cotidiano urbano com relação aos alagamentos, enchentes e inundações foram gerados do crescimento urbano sem controle e planejamento. E hoje impactam na saúde e bem-estar da população (CANHOLI, 2005). A urbanização com tendência em ocupar, primeiro, as áreas próximas a córregos e rios descaracterizou, ocupou e impermeabilizou estas áreas (ANDRADE, 2014; BASTOS, 2009; CANHOLI, 2005). Como protagonista, a urbanização, causa o aumento do escoamento superficial, aumento da geração de sedimentos, redução da qualidade de água e antecipação do tempo da vazão máxima dos rios urbanos (ALEXANDER et al., 2013; ANDRADE, 2014; BASTOS, 2009; CAMPANA, et al., 2000; SAMUEL, 2011; ZYCHOWSKI, 2014)).

A drenagem convencional, existente nos ambientes urbanizados, coleta e transporta o deflúvio por meio de sarjetas e bocas de lobo. Através de rápida remoção com aumento das vazões jusantes, ou seja, transfere os problemas de inundação de um local para outro (BASTOS, 2009; CANHOLI, 2005). A drenagem mais adequada para o fluxo hidrológico, desenvolvimento urbano e redução de catástrofes nos eventos de precipitação intensa são os sistemas de drenagem sustentáveis que drenam as águas pluviais sem causar danos tanto no local, quanto na jusante (TUCCl, et al., 1995; FERNANDES et al, 2008).

A promoção dos sistemas de drenagem sustentáveis aumenta a resiliência urbana e preserva seus recursos hídricos (NEWMAN, 2014; THOMSON \& NEWMAN, 2018).

Com base no cenário instruído, este estudo tem objetivo de promover o estudo da drenagem sustentável para uma avenida do município de Criciúma, estado de Santa Catarina. Este estudo considerou o sistema atual instalado na Avenida e proporcionará o uso combinado entre os sistemas convencional e sustentável com vistas nos princípios biofílico para a resiliência urbana com contiguidade e conectividade urbana.

\section{MATERIAIS E MÉTODOS}

Criciuma, no Estado de Santa Catarina, é a cidade deste estudo. Localizado a $191 \mathrm{~km}$ da capital Florianópolis, com latitude 28040'39" Sul, longitude 49022'11" Oeste e com altitude de 50 metros. O clima da cidade é subtropical com chuvas dispersas em todos os meses do ano com precipitação pluviométrica médias mensais, máximas e mínimas, de 78 e $162 \mathrm{~mm}$, respectivamente (SANTA CATARINA, 2019).

A área deste estudo compreende a $0,12 \mathrm{~km}^{2}$ e pertence a microbacia do Rio Criciuma (ADAMI, 2015). A Avenida deste estudo possui ocupação comercial, com duas pistas de rolamento em sentidos opostos e revestimento asfáltico ao longo de 1.378,00 metros e diferença de nível de 7,00 metros.

Para os valores de infiltração de água no solo foi considerada a ocupação e uso do solo atual da área de contribuição e o sistema de drenagem existente foi considerado para a proposta de uso combinado.

Os dados hidrológicos considerados foram da cidade de Içara - SC para o tempo de duração da chuva entre 5 e 120 minutos e Período de Retorno de 25 anos (BACK, 2013).

A determinação da vazão de pico foi dada através do Método Racional Modificado, equação 1, comumente adotado para determinação das vazões máximas para bacias menores que $3 \mathrm{~km}^{2}$ (SÃO PAULO, 2012).

$Q=$ CiAcf

Onde: $\mathrm{Q}$ é a vazão, em $\mathrm{m}^{3} / \mathrm{s}$; $\mathrm{C}$ é o coeficiente de escoamento superficial, adimensional; i é a intensidade média máxima da chuva, em $\mathrm{mm} / \mathrm{h}$; $\mathrm{A}$ é a área da bacia, em $\mathrm{m}^{2}$; Cf é o coeficiente de ajustamento pelo período de retorno, adimensional, utilizado 1,1.

Os sistemas foram dimensionados com base nas Leis da Hidráulica. A sarjeta através da fórmula de Manning modificada por Izzard, as bocas de lobo pelas fórmulas de vertedores hidráulicos e a trincheira de acordo com o método usado por Tomaz (2011). 


\section{RESULTADOS E CONCLUSÕES}

O diagnóstico da área contabilizou, no trecho estudado, 26 bocas de lobo do tipo guia,10 bocas de lobo do tipo grade e uma boca de lobo combinada, total de 37 bocas de lobo.

O sistema de drenagem atual apresentou problemas estruturais observados in loco e confirmados no dimensionamento hidráulico do sistema. Os problemas foram:

- número insuficiente de bocas de lobo, a área estudada apresentou déficit de 42 bocas de lobo para o adequado funcionamento. Isto origina o acúmulo das águas pluviais na via e passeio;

- sarjetas rasas, ou seja, meio fio baixo com relação a Avenida, e vazão de escoamento superior a capacidade da sarjeta. Isto causa o transbordamento do deflúvio em 16 pontos, da área de estudo, para a pista e/ou passeio;

- pontos da avenida com baixa ou nula declividade longitudinal. A declividade longitudinal é importante para o movimento do escoamento pluvial para alcançar a boca de lobo. Neste caso, há três trechos com declividade nula e velocidades inferiores a mínima recomendada, 0,75 $\mathrm{m} / \mathrm{s}$ (BACK, 2015).

Na proposta para drenagem sustentável com uso combinado de trincheiras de infiltração e bocas de lobo foi obtida redução dos atuais problemas encontrados na avenida.

O uso de trincheiras de infiltração para captar todo o deflúvio da avenida é necessário instalar 55 trincheiras, foi adotado um padrão de trincheiras quadradas de um metro de lados e profundidade de um metro. As trincheiras podem ser implantadas ligadas uma na outra, formando uma grande trincheira linear, preferencialmente na menor cota. Ou implantadas distanciadas ao longo do comprimento de cada trecho. Este último é mais eficaz na redução da vazão de escoamento e dos episódios de extravase das sarjetas.

Na proposta foi observado que os problemas relacionados ao extravasamento das sarjetas passaram a ocorrer em três pontos da avenida, porém, com a redução da velocidade do escoamento pluvial.

A drenagem da área estudada mostrou não comportar a vazão escoada na superfície. $O$ uso das metodologias sustentáveis, aplicadas neste estudo, mostraram ser aplicáveis de forma complementar para drenagem existente. Assim, promoveu a melhoria do sistema de drenagem local e evitou a substituição do sistema de drenagem existente, o que evitou gastos.

\section{REFERÊNCIAS}

ADAMI, R.M. Rio Criciúma: O rio que a cidade escondeu - Significados e representações na paisagem.
Criciuma, SC. UNESC, 2015.

ALEXANDER, C.; ISHIKAWA, S.; SILVERSTEIN, M. Uma linguagem de padrões: a pattern language. Tradução: Alexandre Salvaterra. Porto Alegre: Bookman, 2013.

ANDRADE, L. M. S. Conexão dos padrões espaciais dos ecossistemas urbanos: a construção de um método com enfoque transdisciplinar para o processo de desenho urbano sensível à água no nível da comunidade e da paisagem. Tese (Doutorado em Arquitetura e Urbanismo) - Universidade de Brasília. Brasília, 2014.

BACK, A. J. Chuvas intensas e chuva para o dimensionamento de estruturas de drenagem para o estado de Santa Catarina. (Com programa Hidrom para cálculos). Florianópolis: EPAGRI, 2013.

BACK, A. J. Hidráulica e hidrometria aplicada (Com programa HidroChusc para cálculos). Florianópolis: EPAGRI, 2015.

BASTOS, P. C.. Efeitos da Urbanização sobre Vazões de Pico de Enchente. Dissertação (mestrado em Engenharia Ambiental) - Universidade Federal do Espírito Santo, Espírito Santo, 2009.

CAMPANA, N. A.; TUCCl, C. E. M. Previsão da vazão em macrobacias urbana: arroio dilúvio em Porto Alegre. In: TUCCI, C. E. M.; MARQUES, D. M. L. da M. (org.). Avaliação e controle da Drenagem Urbana. Porto Alegre: Editora da Universidade (UFRGS), 2000.

CANHOLI, A. P. Drenagem Urbana e Controle de Enchentes. São Paulo: Oficina de Textos, 2005.

FERNANDES, M.; KOBAYASHI, F. Y.; FAGGION, F. H. M.; BOSCO, L. M. D.. Drenagem Urbana Sustentável. PHD 2537 - Água em Ambientes Urbanos. São Paulo: Escola Politécnica da Universidade de São Paulo, 2008.

NEWMAN, P. Biophilic urbanism: a case study on Singapore, Australian Planner, 51:1, 47-65. 2014.

SANTA CATARINA. Relatório de Bacias hidrográficas de Santa Catarina. Disponível em: http://www.aguas. sc.gov.br/a-bacia-rio-urussanga/bacia-hidrografica-rio-urussanga. Acesso em: 30/05/2019.

SÃO PAULO (cidade), Secretaria Municipal de Desenvolvimento Urbano. Manual de drenagem e manejo de águas pluviais: aspectos tecnológicos; fundamentos. São Paulo: SMDU, v.2, 2013.

THOMSON, G. \& NEWMAN, P. Urban fabrics and urban metabolism - from sustainable to regenerative cities. Resources, Conservation and Recycling 132 (2018) 218-229. 
TOMAZ, P. Cálculos hidrológicos e hidráulicos para obras municipais. 2. ed. São Paulo: Navegar, 2011.

TUCCI, C. E. M.; PORTO, R. L. L.;BARROS, M.T. Drenagem

Urbana. 1. ed. Porto Alegre. Editora da Universidade/ UFRGS, 1995.

ZYCHOWSKI J. Impact of cemeteries on groundwater bacteriological content. An assessment based on the literature review. IGU Regional Conference, Kraków, Poland. 18-22 August 2014. 
